\title{
IMPLEMENTATION OF BRIDGE MANAGEMENT SYSTEM ON INTERURBAN BRIDGE IN MALUKU PROVINCE
}

\author{
Erwin Marasabessy \\ Public Works Office of Maluku Province, Ambon, Indonesia \\ put_uzumaki@yahoo.co.id
}

\begin{abstract}
Bridges as transport infrastructures play a vital role in smoothing traffic flows. The performance of a bridge in playing its role and serving its function depends on its management. The Government, through the Directorate General of Highways of the Ministry of Public Work has used a system to manage bridges known as the Bridge Management System (BMS). The system allows a systematic plan and provides a uniform procedure for all bridge operation activities on the national and provincial level. Data from Implementation Agency of National Inter-Urban Roads of Area IX, Maluku-Northern Maluku in 2011 indicates that the total length of national roads in Maluku Province is 15,238.01 m. It consist of 562 bridges in total. In Ambon Island, especially, there are 52 bridges whose overall length is $1176 \mathrm{~m}$. The study was conducted at several inter-urban bridges in Maluku Province of Ambon Island: Wai Batu Merah, Wai Ruhu, Wai Lawa, Wai Yari and Wai Tua Bridge. The assessment of bridge structure conditions was conducted visually to determine the conditions of the existing bridges comprehensively by referring to the Bridge Management System (BMS) complemented with a computer-based Bridge Management Information System (BMIS). The assessment results show that the condition scores for Wai Batu Merah, Wai Ruhu, Wai Lawa, Wai Yari, and Wai Tua bridges are 2, 1, 2, 1, and 2, respectively. According to Directorate of Bina Marga, the scores of the five bridges indicate that it is physically in a good condition or in a minor defect. The higher score indicates the poorer condition. Based on technical screening, the proposed treatment for Wai Batu Merah, Wai Ruhu, Wai Lawa, and Wai Tua Bridge is the rehabilitation on their sub-elements. Regarding the Wai Yari Bridge, it should be regularly maintained. The defect repair costs are IDR 149,138,238; IDR 81,048,000; IDR 174,579,106; IDR 79,233,324.- and IDR 238,323,258; for Wai Batu, Wai Ruhu, Wai Lawa, Wai Yari, and Wai Tua Bridges, respectively.
\end{abstract}

Keywords: Bridge, condition score, repair cost.

\section{INTRODUCTION}

Considering the importance of bridges, bridge assessment needs to be conducted to provide safety and convenience for the bridge user. Based on the data from Implementation Agency of National Inter-Urban Roads of Area IX, Maluku-Northern Maluku in 2011, the total length of national roads in Maluku Province is $15,238.01 \mathrm{~m}$. It consist of 562 bridges in total. In Ambon Island, especially, there are 52 bridges whose overall length is $1,176.25 \mathrm{~m}$. Therefore, the objectives of this research are to study the conditions of bridges connecting inter-urban roads in Maluku province, i.e. Wai Batu Merah, Wai Ruhu, Lawa, Yari, and Wai Tua bridges using BMS; to determine the treatment plant that corresponds to the bridge condition scores obtained from technical screening; and also to evaluate a budget plan that accord with bridge damage repair plan. The assessment of bridge defects was conducted visually.

\section{BMS MANAGEMENT INFORMATION SYSTEM (BMS MIS)}

The bridges are parts of the land transport infrastructure that are vital in the traffic flow. The bridges are also frequently served as critical components of a road because they determine the maximum load of vehicles passing through the road. In general, bridge damages that result in the breakdown of traffic flow may paralyze the transportation that in the end disrupts the economy (Triwiyono, 2011a; Triwiyono, 2011b).

The BMS MIS contains a database of bridges and a computer program which allow to entry and retrieval of inspection and other data, to be used as bridges standard report and to make a list of bridges rank or screening the preparation of maintenance and rehabilitation program.

\subsection{Detailed Inspections}

Detailed inspections are carried out to assess the condition of a bridge and its elements in order to prepare the treatment program for each bridges and rank bridges in term of priority for treatment.

\subsection{Element Rating System}

The Element Rating System for defective element consists of a series of 5 questions about the defects present. These questions are concerned with the following aspects: 
a) Structure: whether the structure is harmful or harmless.

b) Degree : whether the failure is minor or major

c) Extensive : whether the defect is extensive or not extensive i.e. does it exist in more or less than $50 \%$ of the element by length, area or volume

d) Function : whether the elements still function or not

e) Effect: The defective element seriously influences other elements or the flow of traffic.

A score of either 1 or 0 is allocated to the element in respect of each defect present, according to the criteria shown in Table 1 (Directorate General of Bina Marga, 1993a; 1993b; 1993c; 1993d; 2008).

Table 1. Determination of condition mark

\begin{tabular}{lll}
\hline Mark & Criteria & Score \\
\hline Structure & Harmful & 1 \\
$(\mathrm{~S})$ & Harmless & 0 \\
Degree (R) & Major & 1 \\
& Minor & 0 \\
Extensive & Extensive-50\% or more is & 1 \\
$(\mathrm{~K})$ & affected by the defect & \\
& Not extensive-less than 50\% is & 0 \\
& affected by the & \\
Function (F) & Element cannot function & 1 \\
& Element still function & 0 \\
Effect (P) & Other element influenced & 1 \\
& Other element not influenced & 0 \\
Condition & CS = S + R + K+ F + P & $0-5$ \\
Score (CS) & & \\
\hline
\end{tabular}

\subsection{Screening and Technical Ranking of Bridges}

The general screening criteria can be seen in Table 2 with the given value followed Directorate of Bina Marga (1993a; 1993b; 1993c; 1993d; 2008).

Table 2. General screening criteria

\begin{tabular}{|c|c|c|c|}
\hline Parameter & Mark & Category & Indicative Treatment \\
\hline \multirow[t]{3}{*}{ Condition } & $0-2$ & Good to fair & $\begin{array}{l}\text { Routine or periodic } \\
\text { Maintenance }\end{array}$ \\
\hline & 3 & Poor & Rehabilitation \\
\hline & $4-5$ & $\begin{array}{l}\text { Critical or } \\
\text { collapse }\end{array}$ & Replacement \\
\hline \multirow[t]{2}{*}{ Traffic } & 0 & Wide enough & Routine maintenance \\
\hline & 5 & Too narrow & $\begin{array}{l}\text { Duplication, } \\
\text { replacement } \\
\text { or widening }\end{array}$ \\
\hline \multirow[t]{2}{*}{ Load } & 0 & Strong enough & Routine maintenance \\
\hline & 5 & $\begin{array}{l}\text { Not meet } \\
\text { standards }\end{array}$ & $\begin{array}{l}\text { Strengthening or } \\
\text { replacement }\end{array}$ \\
\hline
\end{tabular}

The screening process is used to identify the bridges capacity to withstand the traffic load. It detect whether the bridge can safely hold the load or not. The technical ranking provide the priority order for maintenance and rehabilitation program. It is arranged according to the road function classification. The bridges that are in the greatest need of treatment will be placed at the top of the ranking list. Further,

\section{RESEARCH METHODOLOGY}

\subsection{Research Site}

The study was conducted in several bridges that connect provincial roads in Ambon Island. The bridges are as follows:

a) Wai Batu Merah Bridge located on $\mathrm{km} \mathrm{0.4.}$ Structural type: conventional concrete (GTI)

b) Wai Ruhu Bridge located on km 4.05. Structural type: Australia Steel Frame (RBA)

c) Wai Yari Bridge located on km 16.70. Structural type: Pre-stressed Concrete (GPI)

d) Wai Tua Bridge located on $\mathrm{km}$ 29.50. Structural type: Conventional concrete (GTI)

e) Wai Lawa Bridge located on $\mathrm{km} 33.50$. Structural type: Austria steel frame (RBU)

\subsection{Research Method}

The research was conducted by collecting data. The data employed in this study consist of the primary and secondary data. The primary data was obtained by visually observing the bridges condition. Then, it was used to determine the bridge condition score. The secondary data, i.e., road map, traffic data report, bridge inventory report, previous bridge inspection data report, previous unit price in Maluku Province was obtained from Public Work Office of Maluku Province,

\subsection{Data Analysis}

The primary and secondary data were subsequently processed using a computer program that developed in according to Bridge Management Information System (BMIS). After screening, the data were processed to obtain the technical ranking of bridge.

\subsection{Time and Tools}

The current research was conducted from September $8^{\text {th }} 2012$, to December $8^{\text {th }} 2012$. Tools and materials which were used to conduct this research were detailed inspection report form, papers, and pencils, measuring device (meter), camera, flashlight, personal 
computer, Bridge Management Information System (a software).

\section{RESULTS AND DISCUSSION}

The result of visual field observation can be seen in Table 3. The comparison of bridge condition for five Table 3. Bridge Condition Score

\begin{tabular}{|c|c|c|c|c|c|c|c|c|c|c|}
\hline \multirow[t]{2}{*}{ No } & \multirow[t]{2}{*}{ Bridge } & \multicolumn{5}{|c|}{$\begin{array}{l}\text { Condition Score } \\
\text { (CS) }\end{array}$} & \multicolumn{4}{|l|}{ Code } \\
\hline & & 5 & 4 & 3 & 2 & 1 & Defect & Description & Element & Spot \\
\hline \multirow[t]{5}{*}{1} & \multirow{5}{*}{$\begin{array}{l}\text { Wai } \\
\text { Batu } \\
\text { Merah }\end{array}$} & 1 & 1 & 1 & 1 & 2 & 502 & Siltation & 4.212 & Main Chanel \\
\hline & & 2 & 1 & 1 & & & 201 & Falling & 4.411 & Girder (Main) \\
\hline & & 3 & 2 & & & & 202 & Cracking & 4.621 & Post \\
\hline & & 3 & 1 & 2 & 2 & & 205 & Broken/missing & 4.622 & $\begin{array}{l}\text { Horizontal } \\
\text { Railing }\end{array}$ \\
\hline & & 2 & 2 & & & & 204 & Worn, weathered & 4.622 & $\begin{array}{l}\text { Horizontal } \\
\text { Railing }\end{array}$ \\
\hline \multirow[t]{4}{*}{2} & \multirow{4}{*}{$\begin{array}{l}\text { Wai } \\
\text { Tua }\end{array}$} & 3 & 2 & 1 & 2 & 2 & 503 & Scour & 4.212 & Main Chanel \\
\hline & & 4 & 2 & 2 & & & 511 & Missing material & 4.227 & Retaining wall \\
\hline & & 2 & 2 & 2 & 1 & & 511 & Missing material & 4.231 & $\begin{array}{l}\text { Approach } \\
\text { Embankment }\end{array}$ \\
\hline & & 4 & 2 & 1 & & & 511 & Missing material & 4.324 & Wing/Wall \\
\hline 3 & $\begin{array}{l}\text { Wai } \\
\text { Ruhu }\end{array}$ & 3 & 1 & 1 & 1 & 1 & 302 & Corrosion & 4.414 & $\begin{array}{l}\text { Girder } \\
\text { (Connection) }\end{array}$ \\
\hline \multirow[t]{3}{*}{4} & \multirow{3}{*}{$\begin{array}{l}\text { Wai } \\
\text { Lawa }\end{array}$} & 2 & 2 & 2 & 2 & 2 & 503 & Scour & 4.212 & Main Chanel \\
\hline & & 1 & 1 & 1 & & & & & & \\
\hline & & 3 & 1 & & & & 502 & Debris Accumulation & 2 & Main Chanel \\
\hline 5 & $\begin{array}{l}\text { Wai } \\
\text { Yari }\end{array}$ & 3 & 1 & 1 & 1 & 1 & 511 & Missing material & 4.224 & Main Chanel \\
\hline
\end{tabular}

observed bridges can be seen in Table 4 . Based on the technical screening result, as shown in Table 5, it is suggested that rehabilitation of the bridge sub elements should be conducted. 
Table 4. Bridge condition score comparison matrix

\begin{tabular}{|c|c|c|c|c|c|c|c|c|c|c|c|c|c|c|c|}
\hline \multirow{2}{*}{ No } & \multirow{2}{*}{$\begin{array}{l}\text { Bridge } \\
\text { Number }\end{array}$} & \multirow{2}{*}{$\begin{array}{l}\text { Bridge } \\
\text { Name }\end{array}$} & \multirow{2}{*}{ Status } & \multirow{2}{*}{$\mathrm{km}$} & \multirow{2}{*}{$\begin{array}{l}\text { Length } \\
\text { (m) }\end{array}$} & \multirow{2}{*}{$\begin{array}{l}\text { Span number } \\
(\mathrm{sgm})\end{array}$} & \multirow{2}{*}{$\begin{array}{l}\text { Width } \\
\text { (m) }\end{array}$} & \multirow{2}{*}{ BA type } & \multirow{2}{*}{ Year } & \multicolumn{4}{|c|}{ Condition Score } & \multirow{2}{*}{$\begin{array}{l}\text { Traffic } \\
\text { score }\end{array}$} & \multirow{2}{*}{ AADT } \\
\hline & & & & & & & & & & DAS & BB & $\mathrm{BA}$ & JBT & & \\
\hline 1 & 8171.01 .001 .03 & Wai Batu Merah & $\mathrm{N}$ & 0.40 & 18.0 & 2 & 11.50 & GTI & & 1 & 0 & 2 & 2 & 5 & 54.05 \\
\hline 2 & 8171.01 .002 .01 & Wai Ruhu & $\mathrm{N}$ & 4.05 & 80.7 & 1 & 7.00 & RBA & 1992 & 0 & 0 & 1 & 1 & 5 & 63.08 \\
\hline 3 & 8171.01 .004 .18 & Wai Lawa & $\mathrm{N}$ & 3.55 & 41.0 & 1 & 7.00 & RBU & 1978 & 2 & 0 & 0 & 2 & 5 & 27.40 \\
\hline 4 & 8171.01 .005 .07 & Wai Yari & $\mathrm{N}$ & 16.70 & 63.4 & 2 & 7.00 & GPI & 2002 & 1 & 0 & 0 & 1 & 5 & 45.46 \\
\hline 5 & 8171.01 .006 .06 & Wai Tua & $\mathrm{N}$ & 29.50 & 20.5 & 1 & 7.00 & GTI & 1980 & 2 & 1 & 0 & 2 & 5 & 21.26 \\
\hline
\end{tabular}

Table 5. Technical screening report

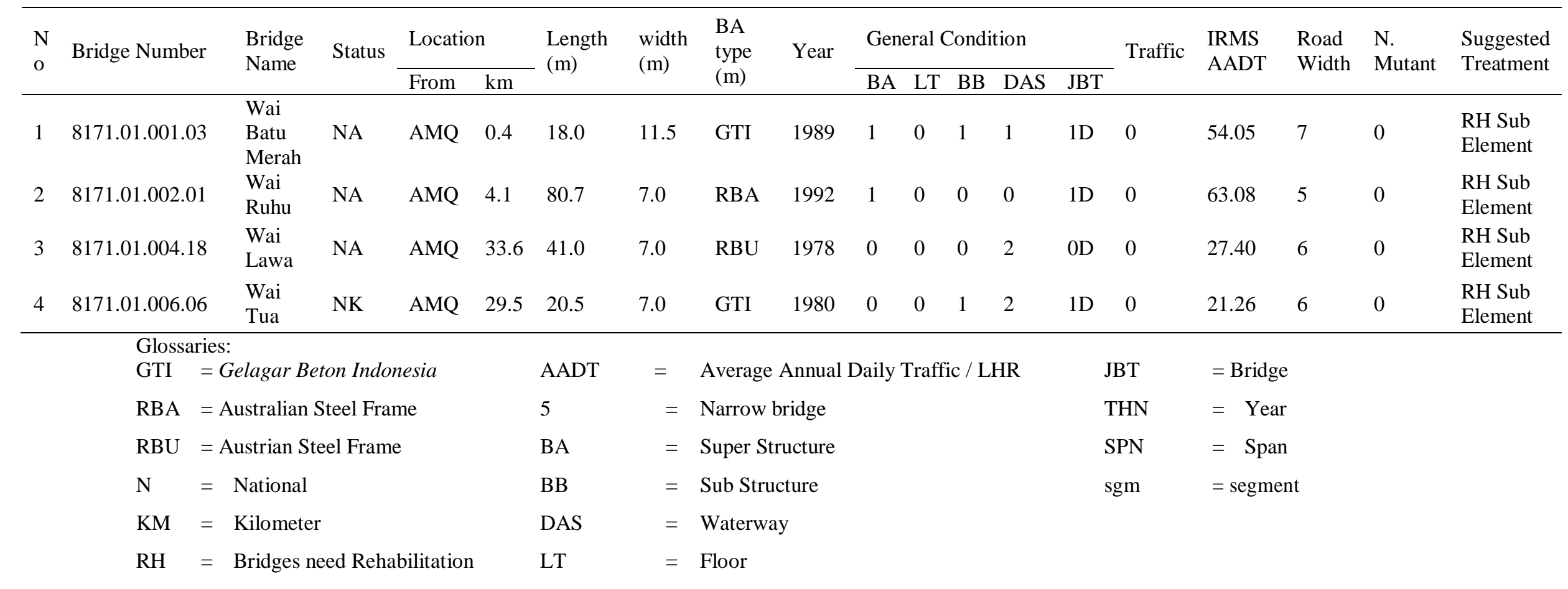




\section{CONCLUSIONS AND SUGGESTIONS}

\subsection{Conclusions}

Based on the aforementioned discussion, it is concluded:

a) The scores of the five bridges for Wai Batu Merah, Wai Ruhu, Wai Lawa, Wai Yari, and Wai Tua Bridge, derived based on a standard BMS, are $2,1,2,1$, and 2 , respectively. Those bridges condition are categorized in good-minor defect.

b) The suggested treatment for Wai Batu Merah, Wai Ruhu, Wai Lawa and Wai Tua Bridges is sub-element rehabilitation, In the case of Wai Yari Bridge, routine maintenance will be advisable.

c) The result of economic evaluation of each bridge for sub-element rehabilitation are Wai Tua Bridge ranks in the $1^{\text {st }}$ priority; Wai Lawa Bridge ranks in the $2^{\text {nd }}$ priority, Wai Batu Merah Bridge ranks in the $3^{\text {rd }}$ priority, Wai Ruhu Bridge rank in the $4^{\text {th }}$ priority. The economic evaluation was not be conducted on Wai Yari Bridge because it is categorized as the one that need routing maintenance.

d) The defect repair costs are IDR 149,138,238.00, IDR $81,048,000.00$, IDR 174,579,106.10, IDR 79,233,324.01 and IDR 238,323,258.60 for Wai Batu, Wai Ruhu, Wai Lawa, ${ }^{\mathrm{ai}}$ Yari, and Wai Tua Bridges, respectively. Thus' the total cost for the five Bridges is IDR 722,381,965.00.

\subsection{Suggestions}

Herewith the suggestions are proposed that may be fruitful for the bridge management research.

a) BMS program is in need of improvement by widening its compatibility so that it can be run on Windows operating systems. b) Technical screening is a sorting out of bridges, a process carried out by BMS computer program based on 2 categories, i.e. condition scores and traffic capacity, excluding load score/load capacity. It is hoped that the scoring system will be more widely used.

\section{REFERENCES}

Directorate General of Bina Marga, 1993a. Sistem Manajemen Jembatan Manual Pemeliharaan dan Rehabilitasi Jembatan [Manual Reference for Bridge Management System and Rehabilitation. s.l.:Ministry of Public Works.

Directorate General of Bina Marga, 1993b. Panduan Pemeriksaan Jembatan (Prosedur Pemeriksaan Jembatan) [Manual Reference for Bridge Assessment (Procedure of Bridge Assessment). s.l.:Ministry of Public Works.

Directorate General of Bina Marga, 1993c. Panduan Prosedur Umum Jembatan [General Procedure of Bridge]. s.l.:Ministry of Public Works.

Directorate General of Bina Marga, 1993d .. Panduan Rencana dan Program Jembatan [Manual Reference for Bridge Design]. s.l.:Ministry of Public Works.

Directorate General of Bina Marga, 2008. Perkuatan Struktur dan Lantai Jembatan [Floor and Structural Bridge Reinforcement]. s.l.:Ministry of Public Works.

Triwiyono, A., 2011a. Panduan Pemeriksaan Jembatan [Manual Reference for Bridge Assessment], Yogyakarta: Universitas Gadjah Mada.

Triwiyono, A., 2011b. Evaluasi dan Rehabilitasi Jembatan" [Evaluation and Rehabilitation of Bridge, Yogyakarta: Universitas Gadjah Mada. 
[this page intentionally left blank] 